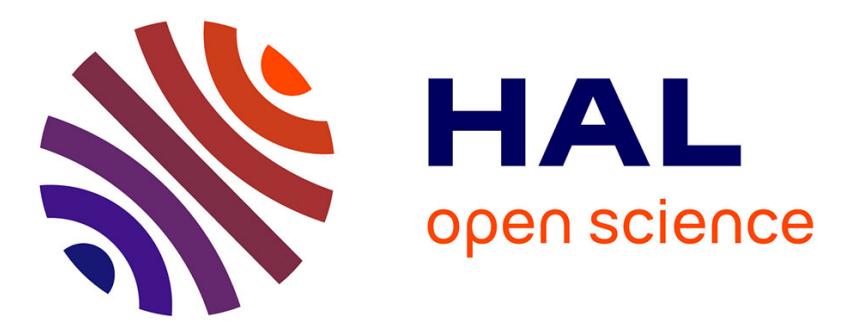

\title{
Conversion of furfural to tetrahydrofuran-derived secondary amines under mild conditions
}

Jiang Shi, Eric Muller, François Jerome, Titus Marc Pera, Karine de Oliveira

Vigier

\section{- To cite this version:}

Jiang Shi, Eric Muller, François Jerome, Titus Marc Pera, Karine de Oliveira Vigier. Conversion of furfural to tetrahydrofuran-derived secondary amines under mild conditions. Green Chemistry, 2020, 22 (6), pp.1832-1836. 10.1039/D0GC00119H . hal-03015048

\section{HAL Id: hal-03015048 \\ https://hal.science/hal-03015048}

Submitted on 19 Nov 2020

HAL is a multi-disciplinary open access archive for the deposit and dissemination of scientific research documents, whether they are published or not. The documents may come from teaching and research institutions in France or abroad, or from public or private research centers.
L'archive ouverte pluridisciplinaire HAL, est destinée au dépôt et à la diffusion de documents scientifiques de niveau recherche, publiés ou non, émanant des établissements d'enseignement et de recherche français ou étrangers, des laboratoires publics ou privés. 


\section{Conversion of furfural to tetrahydrofuran-derived secondary amines under mild conditions}

Received 00th January 20xx,

Shi Jiang, ${ }^{\mathrm{a}, \mathrm{b}}$ Eric Muller, ${ }^{\mathrm{c}}$ François Jerôme, ${ }^{\mathrm{a}}$ Marc Pera-Titus ${ }^{\mathrm{b} *}$ and Karine De Oliveira Vigier ${ }^{\mathrm{a} *}$

Accepted 00th January 20xx

DOI: $10.1039 / \times 0 \times x 00000 x$

The production of amino-containing compounds from biomass is an important goal of research programs. Starting from carbohydratebased furfural, a simple and highly efficient system was developed for producing a library of secondary and tertiary tetrahydrofurfurylamines under mild conditions $\left(25^{\circ} \mathrm{C} / 1\right.$ bar $\left.\mathrm{H}_{2}\right)$ with excellent yields (>90\%). Commercially available $\mathrm{Pd} / \mathrm{Al}_{2} \mathrm{O}_{3}$ proved to be a suitable catalyst and exhibited outstanding performance.

\section{Introduction}

With the depletion of fossil fuel resources, transformation of renewable and abundant biomass into valuable chemicals and functional materials has become a growing field of interest. ${ }^{1}$ To date, the production of a broad range of chemicals from lignocellulose containing $\mathrm{C}, \mathrm{H}$ and $\mathrm{O}$ atoms, such as ethanol, hexitols, furfural, 5-hexamethylfurfural, aldehydes/ketones and acids, attracts continuous exploration. ${ }^{2}$ Nonetheless, the synthesis of added-value $\mathrm{N}$-compounds from biomass-derived platform molecules sugars is still limited and has become an important goal of research programs. ${ }^{3}$

Furfural (FF), issued directly from carbohydrates, is an attractive and commercial platform molecule, which has been identified as one of the top value-added chemicals with huge market potential. ${ }^{4} \mathrm{FF}$ can be used for producing a variety of valuable derivatives, such as furfuryl alcohol, ${ }^{5}$ 2-methylfuran, ${ }^{6}$ succinic acid, ${ }^{7}$ and maleic acid. ${ }^{8}$ FF also can be converted into amino-compounds by reductive amination (RA). Furfurylamine

a.IC2MP UMR CNRS_Université de Poitiers 7285, ENSIP 1 rue Marcel Doré, TSA 41195, 86073 Poitiers Cedex 9, France, Email: karine.vigier@univ-poitiers.fr.

b. Eco-Efficient Products and Processes Laboratory (E2P2L), UMI 3464 CNRS-Solvay, 3966 Jin Du Road, Xin Zhuang Ind. Zone, 201108 Shanghai, China, Email: marc.pera-titus-ext@solvay.com

c. SOLVAY-Advanced Organic Chemistry \& Molecule Design Laboratory, 85 Avenue des Frères Perret, 69192 Saint Fons, France.

Electronic Supplementary Information (ESI) available: [details of any supplementary information available should be included here]. See DOI: 10.1039/x0xx00000x and tetrahydrofurfurylamine are important intermediates in the manufacture of pharmaceuticals (e.g. furosemide), fibers, perfumes, polymers...9-10 ${ }^{9}$ The synthesis of furfurylamines has been investigated from FF and 5-hydroxymethylfurfural by RA using homogeneous and heterogeneous catalysts. ${ }^{11-12}$ In the literature, many works are dedicated to the synthesis of furfurylamine THF-derived amines can be further generated by deep hydrogenation of the furan ring and was used as a regulator in the synthesis of polybutadiene rubber with a precise control of the microstructure, ${ }^{13}$ as well as for the synthesis of poly(2-vinyl-4,4-dimethylazlactone) (pVDMA)derived (co)polymers with lower critical solution temperature. ${ }^{14}$ Alternatively, THF amines can also be synthesized through amination of furfuryl alcohol followed by the saturation of the furan ring in the presence of Raney $\mathrm{Ni}$ at $180^{\circ} \mathrm{C}$, an amine and $0.1 \mathrm{MPa} \mathrm{H} \cdot{ }^{15}$ Homogeneous catalysts such as Ru-acridine complex and triruthenium dodecacarbonyl complex have been also used for such reaction from furfuryl alcohol. ${ }^{16}$ In our group, we synthesized the THF-amines with high yields from furfural trough cascade reaction combining $\mathrm{C}-\mathrm{C}$ and $\mathrm{C}-\mathrm{N}$ condensation reactions in the presence of $\mathrm{Pd} / \mathrm{Al}_{2} \mathrm{O}_{3}$ and Amberlyst 26 catalysts. ${ }^{17}$ Based on these results, it was of interesting to see if this catalyst can be applied to the direct RA of furfural to THFamines.

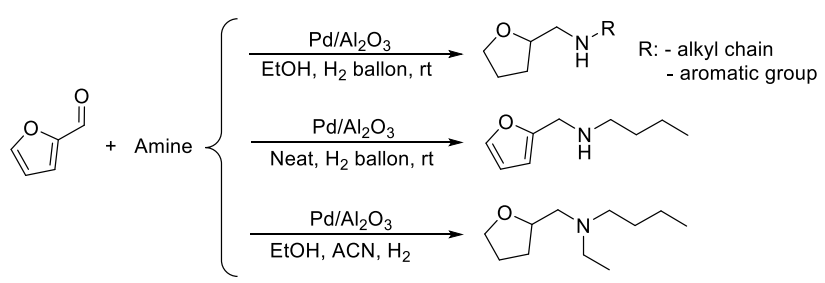

Scheme 1. Library of furan- and THF-derived secondary and tertiary amines that can be achieved by RA of FF with amines over $\mathrm{Pd} / \mathrm{Al}_{2} \mathrm{O}_{3}$.

Here, we report that $\mathrm{Pd} / \mathrm{Al}_{2} \mathrm{O}_{3}$ is an active, selective and recyclable catalyst for the direct RA of FF to secondary THFamines at very mild conditions (Scheme 1 ) in the presence of 
hydrogen and different amines. This strategy was further extended to the one-pot synthesis of tertiary THF-amines using acetonitrile (ACN).

\section{Results and Discussion}

The reaction between FF and 1-butylamine $\left(\mathrm{BuNH}_{2}\right)$ was chosen as a model example. In a first set of experiments, 1 $\mathrm{mmol}$ of $\mathrm{FF}(20 \mathrm{wt} \%$ in $\mathrm{EtOH}$ ) were reacted in $\mathrm{EtOH}$ with $1 \mathrm{mmol}$ of $\mathrm{BuNH}_{2}$ in the presence of $10 \mathrm{mg}$ of supported Pt and $\mathrm{Pd}$ catalysts (5 wt\% metal loading) at room temperature for $12 \mathrm{~h}$ and $0.1 \mathrm{MPa} \mathrm{H}_{2}$ pressure (Table 1, entries 1-5). In all cases, the FF conversion was above $99 \%$ with a carbon balance higher than $90 \%$. When $10 \mathrm{mg}$ of $\mathrm{Pt} / \mathrm{C}$ ( $5 \mathrm{wt} \% \mathrm{Pt}$ ) was used as catalyst (10 wt\% with respect to FF), the furfurylimine (1a) and furfurylamine (2a) were obtained as main products with $20 \%$ and $70 \%$ yield, respectively, whereas the target THF-derived amine (4a) was obtained with only $2 \%$ yield (entry 1 ). $\mathrm{Pt} / \mathrm{Al}_{2} \mathrm{O}_{3}$ exhibited a similar performance with $78 \%$ and $10 \%$ yield of 1 a and $2 \mathrm{a}$, respectively, and trace amounts of 4 a (entry 2 ). A drastically different behaviour was observed over $10 \mathrm{mg} P d$ catalysts ( $0.45 \mathrm{~mol} \%$ with respect to FF), favouring the formation of $4 \mathrm{a}$. $\mathrm{Pd} / \mathrm{Al}_{2} \mathrm{O}_{3}$ exhibited the highest yield $(97 \%)$ of $4 a$ (entry 4). For comparison, $\mathrm{Pd} / \mathrm{C}$ showed $24 \%$ yield of 4 a along with product $2 \mathrm{a}$ with $74 \%$ yield (entry 3 ). In all cases, the THFimine (3a) was not detected.

The $\mathrm{Pd} / \mathrm{Al}_{2} \mathrm{O}_{3}$ catalyst loading was decreased from 10 to 5 mg (entry 5 ), a decline of the 4 a yield from $97 \%$ to $77 \%$ was observed along with an increase of the $2 \mathbf{a}$ yield from $<1 \%$ to $20 \%$. These results point out that $\mathbf{2 a}$ is a reaction intermediate and that depending on the catalyst loading and thus the reaction time, this product can be converted into 4 a or not. A high yield of 4 a $(>95 \%)$ could be attained at shorter times (90 min instead of $12 \mathrm{~h}$ ) by increasing the temperature and $\mathrm{H}_{2}$ pressure to $80{ }^{\circ} \mathrm{C}$ and $1 \mathrm{MPa}$, respectively, with excellent selectvity (entry 6), and the TOF could be increased from 17.9 to $143.3 \mathrm{~h}^{-1}$.

The effect of the solvent was further studied. EtOH favoured the formation of $\mathbf{4 a}$ (entry 4), while THF promoted 2 a with $78 \%$ yield (entry 7). In the presence of toluene, 1a was formed and only traces of $4 \mathbf{a}$ were detected (entry 8 ). Finally, under neat conditions, 2 a was the main product with $85 \%$ yield (entry 9 ), which could be further increased under a slight excess of $\mathrm{BuNH}_{2}$ (entry 10). This difference in the selectivity can be ascribed to the solvent properties as it is reported in the literature. ${ }^{18}$ Protic solvent (ethanol) is more active than aprotic polar and aprotic apolar solvents in such reaction. They promote the reaction between furfural and $\mathrm{BuNH}_{2}$, and they could decreased solventcatalyst interactions that will inhibit the activity of the catalyst in the hydrogenation reaction.

The kinetic profile of the reaction over $\mathrm{Pd} / \mathrm{Al}_{2} \mathrm{O}_{3}$ was studied at room temperature and $0.1 \mathrm{MPa} \mathrm{H}_{2}$ pressure (Fig. 1). Furfurylimine (1a) was spontaneously formed upon contacting $\mathrm{FF}$ with $\mathrm{BuNH}_{2}$. After 30 min of reaction, about $18 \%$ of product $3 a$ was generated along with product $1 \mathrm{a}, 2 \mathrm{a}$ and $4 \mathrm{a}$ with $30 \%$, $50 \%$ and $2 \%$ yield, respectively. Indeed, after another $30 \mathrm{~min}$, product 2 a reached a maximum yield of $72 \%$, at the same time we could get $11 \%$ yield of $3 a$ and $12 \%$ yield of $4 a$. The yield of $4 a$ increased gradually to $97 \%$ after $12 \mathrm{~h}$ on the benefit of $2 \mathrm{a}$ as confirmed by mass/NMR analysis. The reaction rate of the conversion of $\mathbf{3 a}$ to $\mathbf{4 a}$ is slightly higher than the one of $\mathbf{2 a}$ to $\mathbf{4 a}$ $\left(25.1 \mathrm{~h}^{-1}\right.$ vs. $\left.18.8 \mathrm{~h}^{-1}\right)$. Based on previous work ${ }^{11,12}$ and on control experiment, pure $\mathbf{2}$ a could be fully converted to $\mathbf{4 a}$ and $\mathbf{3 a}$ could be also converted to $4 \mathbf{a}$. The reaction pathway of $1 \mathrm{a}$ to $4 \mathrm{a}$ is depicted scheme 2. Furfuryl or THF-alcohol was not detected due to the very fast condensation between $\mathrm{FF}$ and $\mathrm{BuNH}_{2}$.

Table 1. Catalyst screening for the RA of FF with $\mathrm{BuNH}_{2}{ }^{\mathrm{a}}$

\begin{tabular}{|c|c|c|c|c|c|c|}
\hline \multirow{2}{*}{ Entry } & \multirow{2}{*}{ Catalyst } & \multirow{2}{*}{ Solvent } & \multicolumn{3}{|c|}{ Yield / \%[e] } & \multirow{2}{*}{$\operatorname{TOF}^{f}\left(h^{-1}\right)$} \\
\hline & & & $1 a$ & $2 a$ & $4 a$ & \\
\hline 1 & $\mathrm{Pt} / \mathrm{C}$ & $\mathrm{EtOH}$ & 20 & 70 & 2 & 0.4 \\
\hline 2 & $\mathrm{Pt} / \mathrm{Al}_{2} \mathrm{O}_{3}$ & $\mathrm{EtOH}$ & 78 & 10 & $<1$ & - \\
\hline 3 & $\mathrm{Pd} / \mathrm{C}$ & $\mathrm{EtOH}$ & - & 74 & 24 & 4.4 \\
\hline 4 & $\mathrm{Pd} / \mathrm{Al}_{2} \mathrm{O}_{3}$ & $\mathrm{EtOH}$ & - & $<1$ & 97 & 17.9 \\
\hline $5^{[b]}$ & $\mathrm{Pd} / \mathrm{Al}_{2} \mathrm{O}_{3}$ & $\mathrm{EtOH}$ & - & 20 & 77 & 14.2 \\
\hline $6^{[c]}$ & $\mathrm{Pd} / \mathrm{Al}_{2} \mathrm{O}_{3}$ & $\mathrm{EtOH}$ & - & $<1$ & 98 & 143.3 \\
\hline 7 & $\mathrm{Pd} / \mathrm{Al}_{2} \mathrm{O}_{3}$ & THF & $<1$ & 78 & 10 & 1.8 \\
\hline 8 & $\mathrm{Pd} / \mathrm{Al}_{2} \mathrm{O}_{3}$ & Toluene & 27 & 57 & $<1$ & - \\
\hline 9 & $\mathrm{Pd} / \mathrm{Al}_{2} \mathrm{O}_{3}$ & neat & - & 85 & 12 & 2.2 \\
\hline $10^{[\mathrm{d}]}$ & $\mathrm{Pd} / \mathrm{Al}_{2} \mathrm{O}_{3}$ & neat & - & 98 & - & - \\
\hline
\end{tabular}

[a] Reaction conditions: FF (100 mg, 1.04 mmol), BuNH 2 (77 mg), EtOH (5 g), $10 \mathrm{mg}$ of $\mathrm{Pd} / \mathrm{Al}_{2} \mathrm{O}_{3}$ (0.45 mol\% related to furfural), $\mathrm{H}_{2}$ (0.1 MPa), $\mathrm{RT}, 12 \mathrm{~h}$; ${ }^{[b]} 5 \mathrm{mg}$ for $5 \mathrm{wt} \%$ $\mathrm{Pd} / \mathrm{Al}_{2} \mathrm{O}_{3}$ ( $0.225 \mathrm{~mol} \%$ ); [c] $\mathrm{H}_{2}(1 \mathrm{MPa}), 80^{\circ} \mathrm{C}, 90 \mathrm{~min}$; ${ }^{[d]} \mathrm{BuNH}_{2}(116 \mathrm{mg})$; [e] Yield measured on the crude mixture. The FF conversion was $>99 \%$ for all the catalytic tests; ${ }^{[\mathrm{f}]}$ Turnover frequency $(\mathrm{TOF})=(\mathrm{mol}$ of $4 \mathrm{a}$ obtained $) /(\mathrm{mol} \mathrm{Pd} x \mathrm{~h})$.

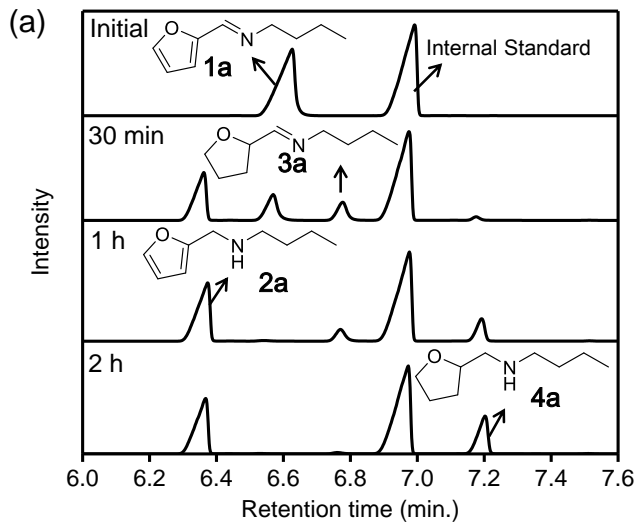




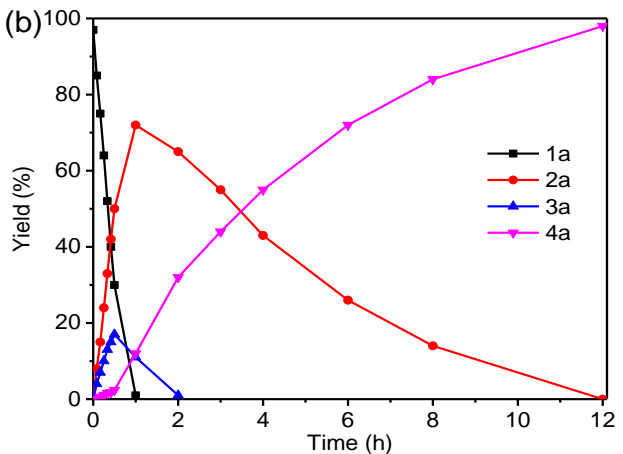

Fig. 1 (a) Representative chromatogram of the products generated along the reaction. (b) Kinetic profile of the $\mathrm{RA}$ of $\mathrm{FF}$ with $\mathrm{BuNH} \mathrm{H}_{2}$ over $\mathrm{Pd} / \mathrm{Al}_{2} \mathrm{O}_{3}$. Reaction conditions: $\mathrm{FF}(100 \mathrm{mg}), \mathrm{BuNH}_{2}(77 \mathrm{mg}), \mathrm{EtOH}(5 \mathrm{~g}), \mathrm{Pd} / \mathrm{Al}_{2} \mathrm{O}_{3}(10 \mathrm{mg}), \mathrm{RT}, \mathrm{H}_{2}$ (0.1 $\mathrm{MPa})$

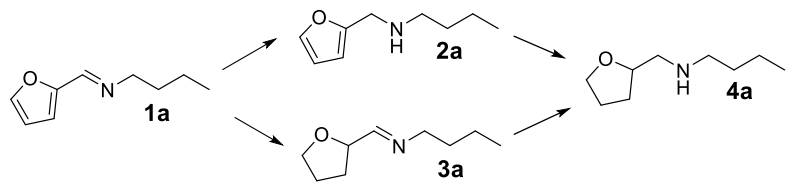

Scheme 2. Reaction pathways for 1 a hydrogenation over $\mathrm{Pd} / \mathrm{Al}_{2} \mathrm{O}_{3}$.

The recyclability of $\mathrm{Pd} / \mathrm{Al}_{2} \mathrm{O}_{3}$ was further investigated (Fig. 2) using the reaction conditions that lead to the highest TOF (143.3 $\left.\mathrm{h}^{-1}\right)$. After each run, the catalyst was separated from the reaction medium by centrifugation and reused without any further pre-treatment. The yield of $4 a$ remained almost constant during the first 5 runs, but displayed a slight decrease after the $7^{\text {th }}$ run at the expense of $\mathbf{2 a}$ while keeping total selectivity to $4 \mathrm{a}$ and $2 \mathrm{a}$ around $95 \%$. The spent catalyst after the $8^{\text {th }}$ run was washed with $\mathrm{EtOH}$ and dried in an oven at $80{ }^{\circ} \mathrm{C}$ overnight.

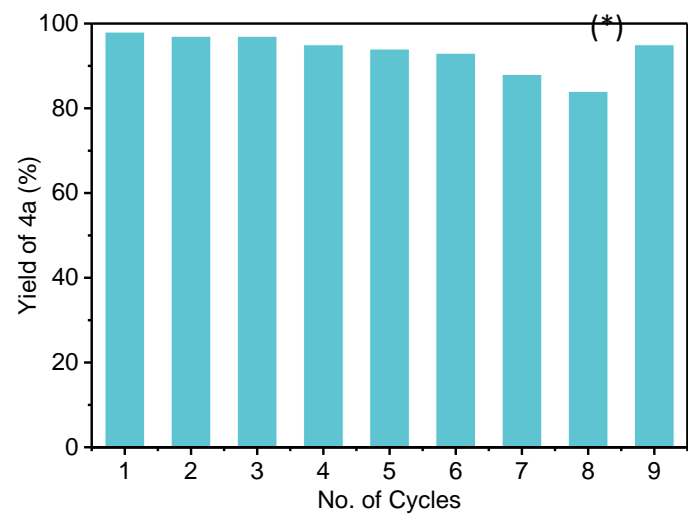

Fig. 2 Evolution of the yield of $4 \mathrm{a}$ in successive catalytic runs. Reaction conditions: FF (2 mmol, $200 \mathrm{mg}$ ), BuNH 2 (2 mmol, $153 \mathrm{mg}$ ), EtOH (10 g), Pd/Al $\mathrm{O}_{3}$ (20 mg), $\mathrm{H}_{2}$ $\neq 1 \mathrm{MPa}), 80{ }^{\circ} \mathrm{C}, 90 \mathrm{~min}$. The label $\left({ }^{*}\right)$ refers to a catalytic run after catalyst calcination at $500{ }^{\circ} \mathrm{C}$ for $90 \mathrm{~min}$.

The spent catalyst was analyzed by thermogravimetric analysis (Fig. S1). Two weight losses were observed at $40{ }^{\circ} \mathrm{C}$ and $250{ }^{\circ} \mathrm{C}$, which were similar to those observed on the fresh catalyst. In contrast, the spent catalyst exhibited three additional weight losses of 1.6 wt\% / $1.1 \mathrm{wt} \%$ / $3.4 \mathrm{wt} \%$ in the range of $250-500{ }^{\circ} \mathrm{C}$, which can be attributed to coke deposits.
By calcining the spent catalyst at $500^{\circ} \mathrm{C}$ for $3 \mathrm{~h}$, almost $95 \%$ yield of 4 a could be recovered after 90 min ( $9^{\text {th }}$ run).

To assess the molecular diversity of THF-amines that could be could obtained through this catalytic pathway, FF was reacted over $\mathrm{Pd} / \mathrm{Al}_{2} \mathrm{O}_{3}$ at room temperature and $0.1 \mathrm{MPa} \mathrm{H}_{2}$ pressure with different amines (Table 2). For alkyl- and alcoholamines, the corresponding THF-derived amines (b-i) were obtained with 91-97\% yield. Besides, with the exception of $\mathrm{N}$-benzylamine ( $47 \%$ yield), aromatic amines afforded THFderived amines with $90-95 \%$ yield. Overall, these results clearly show the efficient and selective one-pot synthesis of THFderived secondary amines over $\mathrm{Pd} / \mathrm{Al}_{2} \mathrm{O}_{3}$ at very mild conditions.

With these results in hand, we attempted the one-pot synthesis of tertiary THF-derived amines over $\mathrm{Pd} / \mathrm{Al}_{2} \mathrm{O}_{3}$ at mild conditions. This reaction is challenging due to steric hindrance disfavouring the formation of iminium/enamine intermediates. A first experiment was carried out with FF and ethylbutylamine at $50^{\circ} \mathrm{C}$ and $1 \mathrm{MPa} \mathrm{H}_{2}$ pressure. A low yield of the tertiary amine (36\%) was achieved after $12 \mathrm{~h}$ due to the formation of furfuyl and THF-alcohols as by-products (Scheme 3 ).

To increase the yield of tertiary THF-amines, FF was reacted with $\mathrm{BuNH}_{2}$ over $\mathrm{Pd} / \mathrm{Al}_{2} \mathrm{O}_{3}$ in EtOH combined with $\mathrm{N}$-alkylation with $\mathrm{ACN}$ at a $\mathrm{FF} / \mathrm{BuNH}_{2} / \mathrm{ACN}$ molar ratio of $1 / 1 / 3$. The kinetic profile showed that $2 \mathrm{a}$ was the primary product generated, which reacted fast by deep hydrogenation of the furan ring to 4a (Fig 3). After $100 \mathrm{~min}$, 4a reached a maximum yield of $93 \%$, which decreased further due to $\mathrm{N}$-alkylation with $\mathrm{ACN}$ at the expense of the $\mathrm{N}, \mathrm{N}$-butylethyl-THF-amine (5a). A possible reaction pathway is proposed in Scheme 4 . The yield of $\mathbf{5 a}$ reached a maximum yield of $84 \%$ after $12 \mathrm{~h}$.

Table 2 Production of THF-derived amines from FF over $\mathrm{Pd} / \mathrm{Al}_{2} \mathrm{O}_{3}{ }^{[a]}$

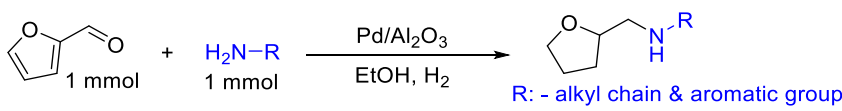

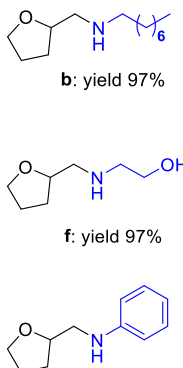

j: yield $93 \%$

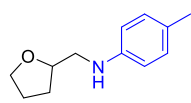

m: yield $94 \%$

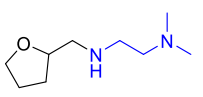

p: yield $90 \%$
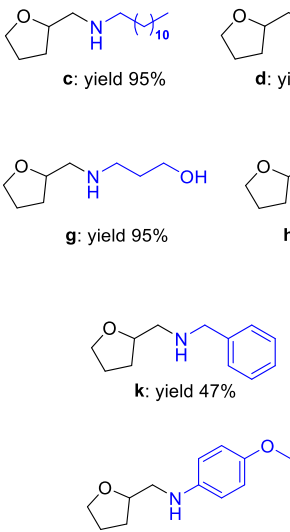

n: yield $90 \%$

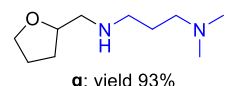

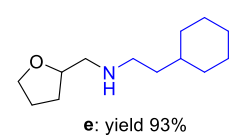

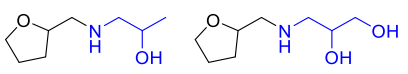

h: yield $93 \%$ [a] Reaction conditions: FF (1 mmol), Amine (1 mmol), EtOH (5 g), Pd/Al $\mathrm{O}_{3}(10 \mathrm{mg})$, $\mathrm{H}_{2}(0.1 \mathrm{MPa}), \mathrm{RT}(\mathrm{b}-\mathrm{i}) / 80^{\circ} \mathrm{C}(\mathrm{j}-\mathrm{r}), 12 \mathrm{~h}$ 
It is of interest to point out that the reaction temperature is a key point which can make a balance between self $\mathrm{N}$-alkylation among acetonitrile and alkylation of THF-butylamine with acetonitrile to obtain a high yield of tertiary amine and high atom-economy (Fig. S2). No tertiary amine (5a) was observed at room temperature, affording the formation of all the products with a yield of $41 \%, 56 \%$ of products $2 a, 4 a$, respectively. A further increase of the reaction temperature to $80{ }^{\circ} \mathrm{C}$ resulted in a decrease of product 5 a maximum yield from $84 \%$ to $69 \%$ along with $28 \%$ yield of $4 a$.

Furthermore, the catalytic performance of $\mathrm{Pd} / \mathrm{Al}_{2} \mathrm{O}_{3}$ proved itself again as a suitable and efficient catalyst for facile synthesis of amines from bio-derived furfural.
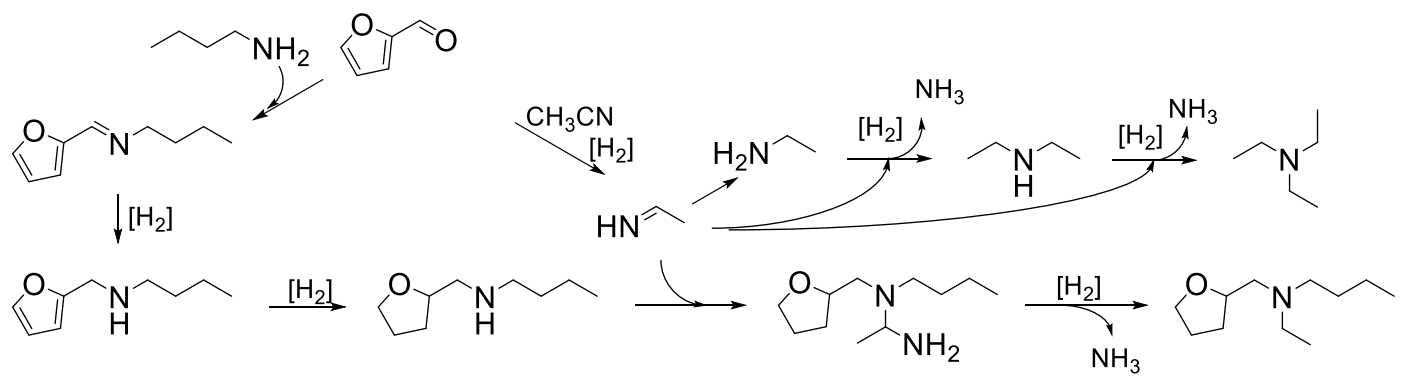

Scheme 4 Proposed reaction pathway for the RA of FF with $\mathrm{BuNH}_{2}$ combined with $\mathrm{N}$-alkylation.

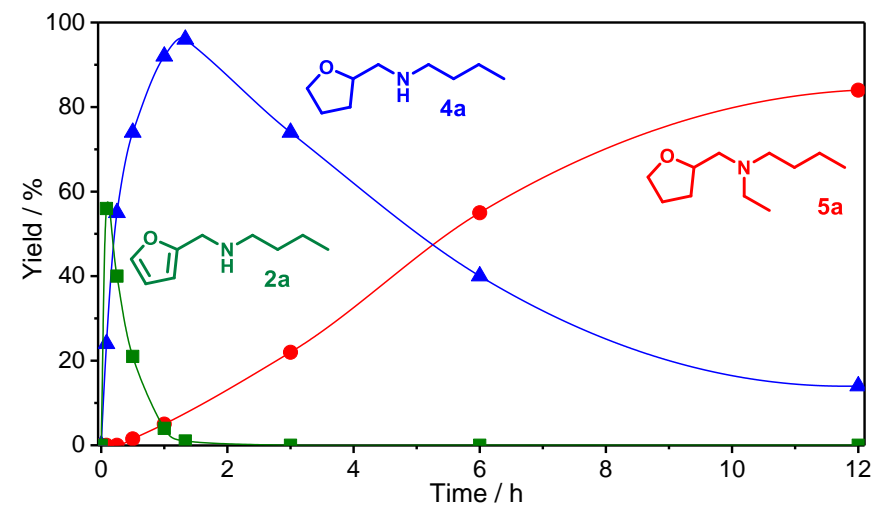

Fig. 3 Kinetic profile of the RA of FF with $\mathrm{BuNH}_{2}$ and $\mathrm{ACN}$ to N,N-butylethyl-THFamine over $\mathrm{Pd} / \mathrm{Al}_{2} \mathrm{O}_{3}$. Reaction conditions: $\mathrm{FF}(1 \mathrm{mmol}), \mathrm{BuNH}_{2}(1 \mathrm{mmol}), \mathrm{EtOH}$ (5 g), $\mathrm{Pd} / \mathrm{Al}_{2} \mathrm{O}_{3}(10 \mathrm{mg}), \mathrm{H}_{2}(1 \mathrm{MPa}), 50^{\circ} \mathrm{C}$.

\section{Conclusions}

We presented in this study the one-pot synthesis of secondary and tertiary THF-derived amines starting from furfural and amines at very mild conditions. Commercially available $\mathrm{Pd} / \mathrm{Al}_{2} \mathrm{O}_{3}$ was found an efficient catalyst for producing a library of amines with excellent yield by simply choosing the solvent. In particular, ethanol favoured the synthesis of tetrahydrofurfurylamine (98\%). By reacting furfural, 1-butylamine and acetonitrile in ethanol, a one-pot multi-reaction could occur favouring the synthesis of N,N-butylethyl-THF-amines.

\section{Conflicts of interest}

There are no conflicts to declare

\section{Acknowledgements}

The authors would like to thank the French ANR agency for the funding of FurCab Project ANR-15-CE07-0016. The authors are also grateful to the Région Nouvelle Aquitaine for the funding of this project through the FR CNRS INCREASE 3707, the chair TECHNOGREEN and FEDER.

\section{References}

1 (a) A. A. Koutinas, C. Du, R. H. Wang and C. Webb, C. Introduction to Chemicals from Biomass, Wiley, Hoboken, 2008, pp. 77; (b) J. J. Bozell and G. R. Petersen, Green Chem., 2010, 12, 539; (c) M. Dusselier, M. Mascal, B. F. Sels, Top. Curr. Chem., 2014, 353, 1. (d) G. W. Huber, S. Iborra and A. Corma, Chem. Rev., 2006, 106, 4044; (d) Y. Liu, Y. Nie, X. Lu, X. Zhang, H. He, F. Pan, L. Zhou, X. Liu, X. Ji and S. Zhang, Green Chem., 2019, 21, 3499.

2 (a) N. Ji, T. Zhang, M. Zheng, A. Wang, H. Wang, X. Wang, J. G. Chen, Angew. Chem. Int. Ed., 2008, 47, 8510; (b) J. Lange, Angew. Chem. Int. Ed., 2015, 54, 13186; (c) A. Wang, T. Zhang, Acc. Chem. Res., 2013, 46, 1377; (d) S. Jiang, C. Verrier, M. Ahmar, J. Lai, C. Ma, E. Muller, Y. Queneau, M. Pera-Titus, F. Jerome, K. De Oliveira Vigier, Green Chem., 2018, 20, 5104.

3 (a) S. Imm, S. Bahn, M. Zhang, L. Neubert, H. Neumann, F. Klasovsky, J. Pfeffer, T. Haas and M. Beller, Angew. Chem. Int. Ed., 2011, 50, 7599; (b) J. Zhang, N. Yan, Green Chem., 2016, 18, 5050; (c) V. Froidevaux, C. Negrell, S. Caillol, J-P. Pascault 
and B. Boutevin, Chem. Rev., 2016, 116, 14181; (d) M. Pelckmans, W. Vermandel, F. V. Waes, K. Mooen and B. F. Sels, Angew. Chem. Int. Ed., 2017, 56, 14540; (e) M. Pelckmans, T. Renders, S. van de Vyver and B. F. Sels, Green Chem., 2017, 19, 5303; (f) N. Brun, P. Hesemann and D. Esposito, Chem. Sci., 2017, 8, 4724.

4 (a) R. Mariscal, P. Maireles-Torres, M. Ojeda, I. Sádaba, M. López Granados, Energy Environ. Sci., 2016, 9, 1144; (b) X. Li, P. Jia, T. Wang, ACS Catal., 2016, 6 (11), 7621; (c) J.-P. Lange, E. van der Heide, J. van Buijtenen, R. Price, ChemSusChem, 2012, 5 (1), 150.

5 Y. Ma, G. Xu, H. Wang, Y. Wang, Y. Zhang and Y. Fu, ACS Catal., 2018, 8, 1268.

6 K. Yan, G. Wu, T. Lafleur and C. Jarvis, Renew. Sust. Energy Rev., 2014, 38, 663.

7 H. Choudhary, S. Nishimura and K. Ebitani, Appl. Catal., A, 2013, 458, 55.

8 N. Araji, D. D. Madjinza, G. Chatel, A. Moores, F. Jerome and K. De Oliveira Vigier, Green Chem., 2017, 19, 98.

9 (a) Q. Girka, N. Hausser, B. Estrine, N. Hoffmann, J. Le Bras, S. Marinkovic and J. Muzart, Green Chem., 2017, 19, 4074; (b) Z.Kuo, C. Bixian, Z. Xiaoting, K. Shimin, X. Yongjun, W. Jinjia, ChemCatChem, 2019, 11, 5562; (c) M. Chatterjee, T. Ishizaka, H. Kawanami, Green Chem., 2016, 18, 487;

10 (a) J. J. Martínez, E. Nope, H. Rojas, M. H. Brijaldo, F. Passos and G. Romanelli, J. Mol. Catal. A: Chem., 2014, 392, 235; (b) X. He, A. H. Conner, J. A. Koutsky, J. Polym. Sci., Part A: Polym. Chem., 1992, 30, 533; (c) T. Ayusawa, S. Mori, T. Aoki and R. Hamana, US4598159, 1986; (d) A. Dunbabin, F. Subrizi, J. M. Ward, T. D. Sheppard and H. C. Hailes, Green Chem., 2017, 19, 397.

11 (a) S. Nishimura, K. Mizuhori and K. Ebitani, Res. Chem. Intermed., 2016, 42, 19; (b) M. Chatterjee, T. Ishizaka and H. Kawanami, Green Chem., 2016, 18, 487; (c) T. Komanoya, T. Kinemura, Y. Kita, K. Kamata and M. Hara, J. Am. Chem. Soc., 2017, 139, 11493; (d) A. Dunbabin, F. Subrizi, J. M. Ward, T. D. Sheppard and H. C. Hailes, Green Chem., 2017, 19, 397; (e) K. Zhou, B. Chen, X. Zhou, S. Kang, Y. Xu, J. Wei, ChemCatChem, 2019, 11, 5562; (f) A. Cukalovic, C. V. Stevens, Green Chem. 2010, 12, 1201.

12 (a) J. A. T. Caetano, A. C. Fernandes, Green Chem., 2018, 20 2494; (b) D. Chandra, Y. Inoue, M. Sasase, M. Kitano, A Bhaumik, K. Kamata, H. Hosono and M. Hara, Chem. Sci., 2018, 9, 5949; (c) V. M. S. Isca and A. C. Fernandes, Green Chem. 2018, 20, 3242; (d) D. Deng, Y. Kita, K. Kamata and M. Hara, ACS Sust. Chem. Eng., 2019, 7, 4692; (e) A. García-Ortiz, J. D. Vidal, M. J. Climent, P. Concepción, A. Corma and S. Iborra, ACS Sust. Chem. Eng., 2019, 7, 6243.

13 (a) Y. Han, X, Chen, M. Lu, CN101845109A, 2010; (b) M, Lu, Y Ji, J. Dong. Y. Han, T. Yang, CN102358757A, 2012; (c) Z. Xiao, J. Zeng, F. Lv, CN103508986B, 2015; (d) L. Lin, W. Chen, Y, Sun, CN106349195A, 2017.

14 (a) Y. Zhu, J. Quek, A. B. Loew, P. J. Roth, Macromolecules, 2013, 46, 6475; (b) Y. Zhu, R. Batchelor, A. B. Lowe, P. J. Roth, Macromolecules, 2016, 49, 672.

15 Y. Liu, K. Zhou, H. Shu, H. Liu, J. Lou, D. Guo, Z. Wei, X. Li, Catal. Sci. Technol., 2017, 7, 4129.

16 (a) C. Gunanathan and D. Milstein, Angew. Chem., Int. Ed. 2008, 47, 8661; (b) S. Imm, S. Bahn, L. Neubert, H. Neumann and M. Beller, Angew. Chem., Int. Ed., 2010, 49, 8126.

17 S. Jiang, C. Ma, E. Muller, M. Pera-Titus, F. Jerôme, K. De Oliveira Vigier, ACS Catal., 2019, 9, 8893

18 S. Song, Y. Wang, N. Yan, Mol. Catal., 2018, 454, 87. 